\title{
Gram-Negative Bacteria and Antibiotic Resistances Isolated from Endotracheal Aspirate Samples of Patients Hospitalized in the Intensive Care Unit: 3-Years Retrospective Analysis
}

\author{
Neslihan Arici (Corresponding author) \\ Uskudar State Hospital, Microbiology Laboratory \\ 34110, Uskudar, Istanbul, Turkey \\ E-mail: dr.neslihan.cicek@gmail.com \\ Sebahat Aksaray \\ University of Health Sciences Turkey, Faculty of Medicine Hamidiye, \\ Department of Medical Microbiology, Uskudar, Istanbul, Turkey \\ E-mail: aksarays@hotmail.com \\ Handan Ankarali \\ Istanbul Medeniyet University, Faculty of Medicine, Department of Biostatistics \\ 34700, Uskudar, Istanbul, Turkey \\ E-mail: handanankarali@gmail.com
}

\begin{abstract}
Intensive care units (ICUs) are the most frequent department where hospital-acquired infections caused by multi-resistant microorganisms. Ventilator-associated pneumonia (VAP) is one of the most common serious infections in intensive care units with high mortality rate. In this study, it was aimed to determine the microorganisms and their antibiotic resistance rates of endotracheal aspirate (ETA) samples taken from patients who applied mechanical ventilation in our hospital's ICU. Gram negative microorganisms isolated from ETA samples sent from patients hospitalized at ICU between January 2016 and December 2018 were included in this study. For identification of the growing strains, matrix-mediated laser desorption ionization-flight time mass spectrometry (MALDI-TOF) (VITEK-MS, bioMérieux, France), VITEK 2 automated system (bioMérieux, France) were used to determine antibiotic susceptibility. The antibiotic susceptibility of the strains was evaluated according to the European Committee on Antimicrobial Susceptibility Testing (EUCAST) criteria. A total of 385 Gram negative microorganisms were isolated from ETA specimens with significant growth over the three-year period. When analyzing the distribution of microorganisms, A. baumannii $(34.2 \%)$ was in the first place, followed by $P$. aeruginosa and $K$. pneumoniae. There was no significant difference in bacterial distribution in the threeyear period. A. baumannii strains showed high levels of carbapenem resistance (94\%), while the most effective antibiotics were colistin and tigecycline. Carbapenem and colistin resistance in $P$. aeruginosa strains were determined as $27 \%$ and $6.5 \%$, respectively. Tigecycline was found to be the most effective antibiotic with $8 \%$ resistance rate in $K$. pneumoniae isolates. The high carbapenem resistance seen in $A$. baumannii strains isolated in our study is remarkable. Increased colistin resistance in $K$. pneumoniae shows that the last line drugs are also in danger. It is thought that following the antimicrobial resistance patterns of the ICU regularly, updating the treatment protocols in this direction and applying the infection control measures carefully will contribute to both the success of the treatment and the reduction of the resistance rates.
\end{abstract}

Keywords: Endotracheal aspirate, intensive care units, antibiotic resistance.

Special Issue of Health Sciences

DOI: $10.7176 /$ JSTR/6-03-31 


\title{
Yoğun Bakım Ünitesi’nde Yatan Hastaların Endotrakeal Aspirat Örneklerinden İzole Edilen Gram Negatif Bakteriler ve Antibiyotik Dirençleri: 3 Yıllık Retrospektif Analiz
}

\begin{abstract}
ÖZET
Yoğun bakım üniteleri (YBÜ), çoğul dirençli mikroorganizmaların neden olduğu hastane kökenli enfeksiyonların en sık görüldüğü bölümlerdir. Ventilatörle ilişkili pnömoni (VİP) yüksek mortalite oranı ile yoğun bakım ünitelerinde sık rastlanan ciddi enfeksiyonların başında gelmektedir. Bu çalışmada, hastanemiz YBÜ'nde mekanik ventilatör uygulanan hastalardan alınan endotrakeal aspirat (ETA) örneklerinden üreyen mikroorganizmaların ve antibiyotik direnç oranlarının belirlenmesi amaçlanmıştır. Bu çalışmaya Ocak 2016-Aralık 2018 tarihleri arasında hastanemiz YBÜ'nde yatan hastalardan gönderilen ETA örneklerinden izole edilen Gram negatif mikroorganizmalar dahil edilmiştir. Üreyen suşların identifikasyonu için matriks aracılı lazer dezorbsiyon iyonizasyon-uçuş zamanlı kütle spektrometresi (MALDI-TOF) (VITEK-MS, bioMérieux, Fransa), antibiyotik duyarlılığının belirlenmesinde VITEK 2 otomatize sistemi (bioMérieux, Fransa) kullanılmıştır. Suşların antibiyotik duyarlılığı, European Committee on Antimicrobial Susceptibility Testing (EUCAST) kriterlerine göre değerlendirilmiştir. Üç yıllık dönemde anlamlı üreme saptanan ETA örneklerinden, toplam 385 Gram negatif mikroorganizma izole edilmiş̧ir. Etkenlerin dağılımı incelendiğinde ilk sırada A.baumannii (\%34.2) yer alırken, bunu P.aeruginosa ve K.pneumoniae takip etmiştir. Üç yıllık dönemde bakteri dağılımında anlamlı fark saptanmamıştır. A.baumannii suşlarında yüksek düzeyde karbapenem direnci (\%94) saptanırken, en etkili antibiyotiklerin kolistin ve tigesiklin olduğu görülmüştür. P.aeruginosa suşlarında karbapenem ve kolistin direnci sırasıyla $\% 27$ ve $\% 6.5$ olarak saptanmıştır. K.pneumoniae izolatlarında $\% 8$ direnç oranı ile tigesiklin en etkili antibiyotik olarak bulunmuştur. Çalışmamızda izole edilen A.baumannii suşlarında görülen yüksek karbapenem direnci dikkat çekici boyuttadır. K.pneumoniae'da artan kolistin direnci son seçenek ilaçların da tehlikede olduğunu göstermektedir. YBÜ'ne ait antimikrobiyal direnç paternlerinin düzenli olarak izlenerek tedavi protokollerinin bu doğrultuda güncellenmesinin ve enfeksiyon kontrol önlemlerinin dikkatle uygulanmasının hem tedavi başarısına hem de direnç oranlarının azaltılmasına önemli katkı sağlayacağı düşünülmüştür.
\end{abstract}

Anahtar kelimeler: Endotrakeal aspirat, yoğun bakım üniteleri, antibiyotik direnci

\section{Giriş}

Yoğun bakım üniteleri (YBÜ), invaziv işlemlerin daha sık uygulanması, uzun yatış süreleri, yatan hastaların sıklıkla immünosüpresif olması nedeniyle hastane enfeksiyonlarının en sık karşılaşıldığı birimlerdir (Uğur ve ark. 2019). Özellikle ventilatörle ilişkili pnömoni (VİP) \%20-70 arasında yüksek mortalite oranı ile yoğun bakım ünitelerinde sık rastlanan ciddi enfeksiyonların başında gelmektedir (Karakeçe ve ark. 2014). VIP tanısı için klinik ve radyolojik bulgular ön planda olmakla birlikte, mikrobiyolojik tanısal işlemler prognozun değerlendirilmesi, uygun tedavinin verilmesi açısından önemlidir (Toksöz ve ark. 2019). Endotrakeal aspirat (ETA) kantitatif kültürü, düşük spesifite ve yanlış pozitiflik oranının yüksek olmasına rağmen, VİP tanısında etkinliği kanıtlanmış ve yaygın kullanılan noninvazif bir mikrobiyolojik tanı yöntemidir (Sağmak Tartar ve ark. 2018, Toksöz ve ark. 2019).

VİP etkenlerinin dağılımı hastanelere, hatta aynı hastane içindeki birimlere göre değişmekle birlikte, ülkemizde son yıllarda Gram negatif bakteriler sıklıkla izole edilmektedir (Özünel ve ark. 2014, Sağmak Tartar ve ark. 2018). Bu bakteriler arasında özellikle Acinetobacter baumannii (A.baumannii), Pseudomonas aeruginosa (P.aeruginosa), Klebsiella pneumoniae (K.pneumoniae) ve Escherichia coli (E.coli) birçok antimikrobiyal ajana karşı artmakta olan dirençleri nedeniyle önem taşımakta ve bu bakterilere bağlı gelişen nozokomiyal infeksiyonların tedavi ve kontrolünde problemler yaşanmaktadır (Hazirolan ve ark. 2016, Djordevic ve ark. 2017, Gupta 2017, Rhodes ve ark. 2018). Uygun ampirik antibiyotik tedavisinin erken başlatılması hasta için hayati öneme sahip olduğundan, etkili bir planlama için patojenlerin sıklığı ve ilaç duyarlılık profillerinin bilinmesi gereklidir (Gupta ve ark. 2017, Djordevic ve ark. 2017). Bu çalışmada YBÜ'den gönderilen ETA kültürlerinden izole edilen Gram negatif mikroorganizmaların dağılımı ve antibiyotik direnç profillerinin araştırılması amaçlanmıştır. 


\section{Yöntemler}

Bu çalışmada Ocak 2016-Aralık 2018 tarihleri arasında Üsküdar Devlet Hastanesi Yoğun Bakım Ünitesi'nde yatan hastalardan alınan endotrakeal aspirat örneklerinin sonuçları geriye dönük olarak incelendi. Laboratuvarımıza gelen endotrakeal aspirat örnekleri; koyun kanlı agar, çikolatamsı agar ve eozin metilen blue agara (EMB) ekimi yapılarak plaklar $35 \pm 2^{\circ} \mathrm{C}$ 'de $24-48$ saat inkübe edildi. Üreyen bakteriler kantitatif olarak değerlendirildi. Koloni sayısı $\geq 10^{5} \mathrm{CFU} / \mathrm{ml}$ olan üremeler klinik açıdan anlamlı olarak değerlendirildi. Aynı hastaya ait yineleyen izolatlar çalışmaya dahil edilmedi. Üreyen suşların identifikasyonu için matriks aracılı lazer dezorbsiyon iyonizasyon-uçuş zamanlı kütle spektrometresi (MALDI-TOF) (VITEK-MS, bioMérieux, Fransa), antibiyotik duyarlılı̆̆ının belirlenmesinde VITEK 2 otomatize sistemi (bioMérieux, Fransa) kullanıldı. Suşların antibiyotik duyarlılı̆̆1, European Committee on Antimicrobial Susceptibility Testing (EUCAST) kriterlerine göre değerlendirildi.

Etik Komite Onayı: Retrospektif olarak verilerin toparlandı̆̆ı, hastalara herhangi bir medikal uygulamanın yapılmadığı bir çalışma olup, etik kurul başvurusu yapılmamıştır.

Hasta Onayı: Retrospektif çalışma olduğu için alınmamıştır.

\section{1. İstatiksel Analiz}

Verilerin tanımlanmasında, sayı ve yüzde frekanslar kullanıldı. Bakteri türleri ve yıllara göre antibiyotik duyarlılığındaki değişim Fisher-Freeman-Halton testi ile incelendi. İstatistiksel anlamlılık düzeyi olarak $\mathrm{p}<0.05$ kabul edildi. Elde edilen verilerin istatistiksel değerlendirmesi IBM SPSS Statistics 22 (IBM SPSS, Türkiye) programı ile yapıldı.

\section{Bulgular}

Üç yıllık periyotta anlamlı üreme saptanan ETA örneklerinden toplam 385 Gram negatif mikroorganizma izole edildi. İzole edilen bakteriler sıklık sırasına göre değerlendirildiğinde; ilk sırada \%34.2 Acinetobacter baumannii $(\mathrm{n}=131)$ yer alırken bunu sirasiyla, \%23.1 Klebsiella pneumoniae $(\mathrm{n}=89)$, \%16.6 Pseudomonas aeruginosa $(\mathrm{n}=64)$, ve \%7.8 Escherichia coli $(\mathrm{n}=91)$ izledi. Daha az sıkl1kta izole edilen diğer mikroorganizmaların ise Citrobacter spp., Enterobacter spp., Proteus spp., Providencia spp., Serratia spp. ve Stenotrophomonas maltophilia olduğu görüldü. Çalışılan bakteri türlerinin yıllara göre dağılımı incelendiğinde her üç yılda da dağılımın benzer olduğu, anlamlı değişim göstermediği görüldü $(\mathrm{p}=0.148)$ (Tablo 1). Nonfermentatif Gram-negatif mikroorganizmaların çeşitli antibiyotiklere direnç oranları Tablo 2'de gösterilmiştir. A.baumannii ve P.aeruginosa'da imipenem direnci sırasıla \%94 ve $\% 27$ olarak bulunurken, kolistin direnci sırasıyla \%1 ve \%6.5 olarak saptanmıştır. P.aeruginosa suşlarının kolistin dişındaki diğer tüm antibiyotiklere A.baumannii'ye göre istatiksel olarak anlamlı düzeyde daha duyarlı olduğu görülmüştür $(\mathrm{p}<0.05)($ Tablo2). Enterobacteriacea grubuna ait bakterilerin antibiyotik duyarlılık oranları ve karşılaştırmalı analizi Tablo 3'de verilmiştir. İlaçlara duyarlılık bakımından Enterobacteriacea grubu bakteriler karşılaştırıldığında, kolistin, meropenem ve imipenem duyarlılı̆̆ 1 , Escherichia coli 'de K.pneumoniae' ya göre anlamlı düzeyde daha yüksek oranda bulunmuştur (p=0.011). K.pneumoniae' da \%15 olarak saptanan kolistin direnci, E.coli'de \%2, meropenem direnci ise sirasiyla $\% 29$ ve \%7.5 olarak saptanmıştır. Kolistin direncinin bakteri türleri ve yıllara göre dağılımı Tablo 4’te verilmiştir. K.pneumoniae için en etkili antibiyotiğin \%8 direnç oranı ile tigesiklin olduğu görülmüştür.

Tablo 1. İzole edilen bakterilerin yıllara göre dağılımı

\begin{tabular}{|c|c|c|c|c|c|c|c|c|}
\hline & \multicolumn{2}{|c|}{2016} & \multicolumn{2}{|c|}{2017} & \multicolumn{2}{|c|}{2018} & \multicolumn{2}{|c|}{ Toplam } \\
\hline Mikroorganizma & $\mathrm{n}$ & $\%$ & $\mathrm{n}$ & $\%$ & $\mathrm{n}$ & $\%$ & $\mathrm{n}$ & $\%$ \\
\hline Acinetobacter baumannii & 22 & 36.1 & 44 & 36.7 & 65 & 31.9 & 131 & 34.2 \\
\hline Pseudomonas aeruginosae & 8 & 13.1 & 21 & 17.5 & 35 & 17.2 & 64 & 16.6 \\
\hline Stenotrophomonas & 2 & 3.3 & 7 & 5.8 & 2 & 1.0 & 11 & 2.8 \\
\hline Escherichia coli & 6 & 9.8 & 14 & 11.7 & 33 & 16.2 & 53 & 13.7 \\
\hline Klebsiella pneumoniae & 13 & 21.3 & 23 & 19.2 & 53 & 26.0 & 89 & 23.1 \\
\hline Diğer* & 10 & 16.4 & 11 & 9.2 & 16 & 7.8 & 37 & 9.6 \\
\hline & 61 & & 120 & & 204 & & 385 & \\
\hline
\end{tabular}


Tablo 2. NF grubu bakterilerin ilaçlara duyarlılık seviyeleri ve karşılaştımalı analizi

\begin{tabular}{|c|c|c|c|c|c|c|c|c|}
\hline & & \multicolumn{6}{|c|}{ NF } & \multirow{3}{*}{$\mathbf{P}^{\mathbf{a}}$} \\
\hline & & \multicolumn{2}{|c|}{ A.baumannii } & \multicolumn{2}{|c|}{ P.aeruginosa } & \multicolumn{2}{|c|}{ S.maltophilia } & \\
\hline & & $\mathbf{N}$ & $\%$ & $\mathbf{N}$ & $\%$ & $\mathbf{N}$ & $\%$ & \\
\hline \multirow{3}{*}{ Amikasin } & Duyarlı & 43 & $33.1^{\mathrm{a}}$ & 43 & $69.4^{b}$ & & & \multirow{3}{*}{0.001} \\
\hline & Orta Duyarlı & 4 & $3.1^{\mathrm{a}}$ & 3 & $4.8^{\mathrm{a}}$ & & & \\
\hline & Dirençli & 83 & $63.8^{a}$ & 16 & $25.8^{\mathrm{b}}$ & & & \\
\hline \multirow{2}{*}{ Colistin } & Duyarlı & 129 & $99.2^{\mathrm{a}}$ & 58 & $93.5^{\mathrm{b}}$ & & & \multirow{2}{*}{0.038} \\
\hline & Dirençli & 1 & $0.8^{\mathrm{a}}$ & 4 & $6.5^{\mathrm{b}}$ & & & \\
\hline \multirow{3}{*}{ Meropenem } & Duyarlı & 6 & $4.6^{\mathrm{a}}$ & 43 & $69.4^{b}$ & & & \multirow{3}{*}{0.001} \\
\hline & Orta Duyarlı & 2 & $1.5^{\mathrm{a}}$ & 7 & $11.3^{\mathrm{b}}$ & & & \\
\hline & Dirençli & 122 & $93.8^{\mathrm{a}}$ & 12 & $19.4^{b}$ & & & \\
\hline \multirow{3}{*}{ İmipenem } & Duyarlı & 8 & $6.2^{\mathrm{a}}$ & 38 & $63.3^{\mathrm{b}}$ & & & \multirow{3}{*}{0.001} \\
\hline & Orta Duyarlı & 0 & $0.0^{\mathrm{a}}$ & 6 & $10.0^{\mathrm{b}}$ & & & \\
\hline & Dirençli & 121 & $93.8^{a}$ & 16 & $26.7^{b}$ & & & \\
\hline Ertapenem & Dirençli & 1 & 100.0 & 1 & 100.0 & & & \\
\hline \multirow{3}{*}{ Gentamisin } & Duyarlı & 26 & $20.0^{\mathrm{a}}$ & 42 & $67.7^{b}$ & & & \multirow{3}{*}{0.001} \\
\hline & Orta Duyarlı & 5 & $3.8^{\mathrm{a}}$ & 0 & $0.0^{\mathrm{a}}$ & & & \\
\hline & Dirençli & 99 & $76.2^{\mathrm{a}}$ & 20 & $32.3^{\mathrm{b}}$ & & & \\
\hline \multirow{3}{*}{$\begin{array}{l}\text { Piperasilin/ } \\
\text { tazobaktam }\end{array}$} & Duyarlı & 3 & $2.4^{\mathrm{a}}$ & 25 & $41.7^{b}$ & & & \multirow{3}{*}{0.000} \\
\hline & Orta Duyarlı & 0 & $0.0^{\mathrm{a}}$ & 5 & $8.3^{b}$ & & & \\
\hline & Dirençli & 121 & $97.6^{\mathrm{a}}$ & 30 & $50.0^{\mathrm{b}}$ & & & \\
\hline \multirow{3}{*}{ Sefepim } & Duyarlı & 0 & $0.0^{\mathrm{a}}$ & 36 & $59.1^{\mathrm{b}}$ & & & \multirow{3}{*}{0.001} \\
\hline & Orta Duyarlı & 1 & $3.6^{\mathrm{a}}$ & 1 & $1.6^{\mathrm{a}}$ & & & \\
\hline & Dirençli & 27 & $96.4^{\mathrm{a}}$ & 24 & $39.3^{\mathrm{b}}$ & & & \\
\hline \multirow{3}{*}{ Seftazidim } & Duyarlı & 3 & $2.3^{\mathrm{a}}$ & 36 & $58.1^{\mathrm{b}}$ & 3 & $7.1^{\mathrm{a}}$ & \multirow{3}{*}{0.001} \\
\hline & Orta Duyarlı & 0 & $0.0^{\mathrm{a}}$ & 4 & $6.5^{\mathrm{b}}$ & 1 & $20.0^{\mathrm{b}}$ & \\
\hline & Dirençli & 126 & $97.7^{\mathrm{a}}$ & 22 & $35.5^{b}$ & 4 & $2.6^{\mathrm{b}}$ & \\
\hline Seftriakson & Dirençli & 4 & 100.0 & 0 & 0.0 & & & \\
\hline \multirow{3}{*}{ Siprofloksasin } & Duyarlı & 4 & $3.1^{\mathrm{a}}$ & 31 & $50.0^{\mathrm{b}}$ & & & \multirow{3}{*}{0.001} \\
\hline & Orta Duyarlı & 0 & $0.0^{\mathrm{a}}$ & 1 & $1.6^{\mathrm{a}}$ & & & \\
\hline & Dirençli & 126 & $96.9^{\mathrm{a}}$ & 30 & $48.4^{\mathrm{b}}$ & & & \\
\hline \multirow{3}{*}{ Tigesiklin } & Duyarlı & 72 & $60.5^{\mathrm{a}}$ & 0 & $0.0^{\mathrm{b}}$ & & & \multirow{3}{*}{0.001} \\
\hline & Orta Duyarlı & 41 & $34.5^{\mathrm{a}}$ & 0 & $0.0^{\mathrm{b}}$ & & & \\
\hline & Dirençli & 6 & $5.0^{\mathrm{a}}$ & 9 & $100.0^{\mathrm{b}}$ & & & \\
\hline & Duyarlı & 29 & $23.6^{\mathrm{a}}$ & 44 & $74.6^{\mathrm{b}}$ & & & \\
\hline Tobramisin & Orta Duyarlı & 0 & $0.0^{\mathrm{a}}$ & 1 & $1.7^{\mathrm{a}}$ & & & 0.001 \\
\hline & Dirençli & 94 & $76.4^{\mathrm{a}}$ & 14 & $23.7^{b}$ & & & \\
\hline & Duyarlı & 30 & $23.1^{\mathrm{a}}$ & 0 & $0.0^{\mathrm{b}}$ & 10 & $90.9^{\mathrm{b}}$ & \\
\hline $\begin{array}{c}\text { 1rimetoprim / } \\
\text { sulfametoksazol }\end{array}$ & Orta Duyarlı & 1 & $0.8^{\mathrm{a}}$ & 0 & $0.0^{\mathrm{a}}$ & 0 & $0.0^{\mathrm{a}}$ & 0.001 \\
\hline & Dirençli & 99 & $76.2^{\mathrm{a}}$ & 3 & $100^{\mathrm{b}}$ & 1 & $9.1^{b}$ & \\
\hline
\end{tabular}




\begin{tabular}{|c|c|c|c|c|c|c|c|c|}
\hline & & \multicolumn{6}{|c|}{ Enterobacteriacea } & \multirow{3}{*}{$\mathbf{P}^{\mathbf{a}}$} \\
\hline & & \multicolumn{2}{|c|}{ E.coli } & \multicolumn{2}{|c|}{ K.pneumonia } & \multicolumn{2}{|c|}{ Diğer } & \\
\hline & & $\mathbf{N}$ & $\%$ & $\mathbf{N}$ & $\%$ & $\mathbf{N}$ & $\%$ & \\
\hline \multirow{3}{*}{ Amikasin } & Duyarlı & 40 & $75.5^{\mathrm{ab}}$ & 56 & $62.9^{\mathrm{a}}$ & 33 & $82.5^{\mathrm{b}}$ & \multirow{3}{*}{0.004} \\
\hline & Orta Duyarlı & 12 & 22.6 & 16 & 18.0 & 6 & 15.0 & \\
\hline & Dirençli & 1 & $1.9^{\mathrm{ab}}$ & 17 & $19.1^{\mathrm{a}}$ & 1 & $2.5^{\mathrm{b}}$ & \\
\hline \multirow{2}{*}{ Colistin } & Duyarlı & 52 & $98.0^{\mathrm{a}}$ & 76 & $85.4^{\mathrm{b}}$ & $21^{\mathrm{a}}$ & 100.0 & \multirow{2}{*}{0.011} \\
\hline & Dirençli & 1 & $1.9^{\mathrm{a}}$ & 13 & $14.6^{\mathrm{b}}$ & 0 & 0.0 & \\
\hline \multirow{3}{*}{ Meropenem } & Duyarlı & 49 & $92.5^{\mathrm{a}}$ & 61 & $68.5^{\mathrm{b}}$ & 38 & $95.0^{\mathrm{a}}$ & \multirow{3}{*}{0.001} \\
\hline & Orta Duyarlı & 0 & 0.0 & 2 & 2.2 & 1 & 2.5 & \\
\hline & Dirençli & 4 & $7.5^{\mathrm{a}}$ & 26 & $29.2^{\mathrm{b}}$ & 1 & $2.5^{\mathrm{a}}$ & \\
\hline \multirow{3}{*}{ İmipenem } & Duyarlı & 46 & $100.0^{\mathrm{a}}$ & 55 & $69.6^{\mathrm{b}}$ & 24 & $92.3^{\mathrm{a}}$ & \multirow{3}{*}{0.001} \\
\hline & Orta Duyarlı & 0 & 0.0 & 1 & 1.3 & 0 & 0.0 & \\
\hline & Dirençli & 0 & $0.0^{\mathrm{a}}$ & 23 & $29.1^{\mathrm{b}}$ & 2 & $7.7^{\mathrm{a}}$ & \\
\hline \multirow{3}{*}{ Ertapenem } & Duyarlı & 49 & $92.5^{\mathrm{a}}$ & 60 & $68.2^{\mathrm{b}}$ & 38 & $95.0^{\mathrm{a}}$ & \multirow{3}{*}{0.001} \\
\hline & Orta Duyarlı & 0 & 0.0 & 1 & 1.1 & 1 & 2.5 & \\
\hline & Dirençli & 4 & $7.5^{\mathrm{a}}$ & 27 & $30.7^{b}$ & 1 & $2.5^{\mathrm{a}}$ & \\
\hline \multirow{2}{*}{ Gentamisin } & Duyarlı & 39 & $73.6^{\mathrm{ab}}$ & 54 & $60.7^{\mathrm{b}}$ & 33 & $82.5^{\mathrm{a}}$ & \multirow{2}{*}{0.035} \\
\hline & Dirençli & 14 & $26.4^{\mathrm{ab}}$ & 35 & $39.3^{\mathrm{b}}$ & 7 & $17.5^{\mathrm{a}}$ & \\
\hline \multirow{3}{*}{$\begin{array}{l}\text { Piperasilin / } \\
\text { tazobaktam }\end{array}$} & Duyarlı & 26 & $49.1^{\mathrm{a}}$ & 33 & $37.1^{\mathrm{a}}$ & 26 & $81.3^{\mathrm{b}}$ & \multirow{3}{*}{0.001} \\
\hline & Orta Duyarlı & 8 & $15.1^{\mathrm{a}}$ & 15 & $16.9^{\mathrm{a}}$ & 1 & $3.1^{\mathrm{b}}$ & \\
\hline & Dirençli & 19 & $35.8^{\mathrm{a}}$ & 41 & $46.1^{\mathrm{a}}$ & 5 & $15.6^{\mathrm{b}}$ & \\
\hline \multirow{3}{*}{ Sefepim } & Duyarlı & 17 & $34.0^{\mathrm{a}}$ & 29 & $34.5^{\mathrm{a}}$ & 32 & $84.2^{\mathrm{b}}$ & \multirow{3}{*}{0.001} \\
\hline & Orta Duyarlı & 6 & 12.0 & 3 & 3.6 & 2 & 5.3 & \\
\hline & Dirençli & 27 & $54.0^{\mathrm{a}}$ & 52 & $61.9^{\mathrm{a}}$ & 4 & $10.5^{\mathrm{b}}$ & \\
\hline \multirow{3}{*}{ Seftazidim } & Duyarlı & 16 & $30.2^{\mathrm{a}}$ & 31 & $34.8^{\mathrm{a}}$ & 31 & $77.5^{\mathrm{b}}$ & \multirow{3}{*}{0.001} \\
\hline & Orta Duyarlı & 5 & 9.4 & 6 & 6.7 & 2 & 5.0 & \\
\hline & Dirençli & 32 & $60.4^{\mathrm{a}}$ & 52 & $58.4^{\mathrm{a}}$ & 7 & $17.5^{\mathrm{b}}$ & \\
\hline \multirow{3}{*}{ Seftriakson } & Duyarlı & 17 & $32.1^{\mathrm{a}}$ & 27 & $30.7^{\mathrm{a}}$ & 30 & $75.0^{\mathrm{b}}$ & \multirow{3}{*}{0.001} \\
\hline & Orta Duyarlı & 0 & 0.0 & 3 & 3.4 & 3 & 0.0 & \\
\hline & Dirençli & 36 & $67.9^{\mathrm{a}}$ & 58 & $65.9^{\mathrm{a}}$ & 10 & $25.0^{\mathrm{b}}$ & \\
\hline & Duyarlı & 14 & $26.4^{\mathrm{a}}$ & 35 & $39.3^{\mathrm{a}}$ & 32 & $80.0^{\mathrm{b}}$ & \\
\hline Siprofloksasin & Orta Duyarlı & 0 & 0.0 & 4 & 4.5 & 2 & 5.0 & 0.001 \\
\hline & Dirençli & 39 & $73.6^{\mathrm{a}}$ & 50 & $56.2^{\mathrm{a}}$ & 6 & $15.0^{\mathrm{b}}$ & \\
\hline & Duyarlı & 49 & $98.0^{\mathrm{a}}$ & 56 & $66.7^{b}$ & 23 & $60.5^{\mathrm{b}}$ & \\
\hline Tigesiklin & Orta Duyarlı & 1 & $2.0^{\mathrm{a}}$ & 20 & $23.8^{\mathrm{b}}$ & 7 & $18.4^{\mathrm{b}}$ & 0.001 \\
\hline & Dirençli & 0 & $0.0^{\mathrm{a}}$ & 8 & $9.5^{\mathrm{a}}$ & 8 & $21.1^{\mathrm{b}}$ & \\
\hline Trimetoprim / & Duyarlı & 22 & $42.3^{\mathrm{a}}$ & 49 & $55.7^{\mathrm{a}}$ & 33 & $82.5^{\mathrm{b}}$ & \\
\hline sulfametoksazol & Dirençli & 30 & $57.7^{\mathrm{a}}$ & 39 & $44.3^{\mathrm{a}}$ & 7 & $17.5^{b}$ & 0.001 \\
\hline
\end{tabular}


Tablo 4. Kolistin duyarlılık/dirençlilik sonuçlarının bakteri türleri ve yıllara göre dağılımı

\begin{tabular}{|c|c|c|c|c|c|c|c|c|}
\hline \multirow[b]{2}{*}{ BAKTERI } & \multirow[b]{2}{*}{ Kolistin } & \multicolumn{2}{|c|}{2016} & \multicolumn{2}{|c|}{2017} & \multicolumn{2}{|c|}{2018} & \multirow[t]{2}{*}{$\mathrm{P}$} \\
\hline & & $\mathrm{n}$ & $\%$ & $\mathrm{n}$ & $\%$ & $\mathrm{n}$ & $\%$ & \\
\hline \multirow[t]{2}{*}{ A.baumanni } & DUYARLI & 22 & 100,0 & 43 & 97,7 & 65 & 100,0 & \multirow[t]{2}{*}{0.503} \\
\hline & DİRENÇLI & 0 & 0,0 & 1 & 2,3 & 0 & 0,0 & \\
\hline \multirow[t]{2}{*}{ P.aeruginosa } & DUYARLI & 8 & 100,0 & 20 & 95,2 & 32 & 91,4 & \multirow[t]{2}{*}{0.627} \\
\hline & DİRENÇLİ & 0 & 0,0 & 1 & 4,8 & 3 & $\overline{8,6}$ & \\
\hline \multirow[t]{2}{*}{ E.coli } & DUYARLI & 5 & 83,3 & 14 & 100,0 & 32 & 97,0 & \multirow[t]{2}{*}{0.282} \\
\hline & DİRENÇLI & 1 & 16,7 & 0 & 0,0 & 1 & 3,0 & \\
\hline \multirow[t]{2}{*}{ K.pneumoniae } & DUYARLI & 13 & 100,0 & 20 & 90,9 & 43 & 81,1 & \multirow[t]{2}{*}{0.400} \\
\hline & DİRENÇLİ & 0 & 0,0 & 2 & 9,1 & 10 & 18,9 & \\
\hline \multirow[t]{2}{*}{ Diğer } & DUYARLI & 5 & 100,0 & 7 & 100,0 & 7 & 100,0 & \multirow[t]{2}{*}{0.194} \\
\hline & DİRENÇLI & 5 & 100,0 & 7 & 100,0 & 7 & 100,0 & \\
\hline
\end{tabular}

\section{Tartışma}

Alt solunum yolu enfeksiyonları YBÜ'de görülen hastane enfeksiyonları arasında ilk siralarda yer alır. VİP etkenlerinin dağılımı hastanelere göre değişmekle birlikte ülkemizde genel olarak Gram negatif bakteriler izole edilmektedir (Sağmak Tartar ve ark. 2018). Gram negatif bakteriler arasında da, A.baumannii ve P.aeruginosa gibi non-fermentatiflerin, etkenlerin büyük çoğunluğunu oluşturduğu bilinmektedir (Chung ve ark. 2011, Özünel ve ark. 2014, Wang ve ark. 2018). Bizim çalışmamızda da endotrakeal aspirat kültürlerinden izole ettiğimiz mikroorganizmaların \%53.6'sını (\%34 A.baumannii ve $\% 17$ P.aeruginosa) non-fermentatif bakteriler oluşturmaktayken, bunu \%23 ile K.pneumoniae, \%14 ile E.coli takip etmiştir. Ülkemizde son yıllarda endotrakeal aspirat kültürleri ile yapılan çalışmalar incelendiğinde, izole edilen bakterilerin, çalışmamızla aynı sıralamaya sahip olduğu görülmüştür (Koçak ve ark. 2019, Aydemir ve ark. 2016, Karakeçe ve ark. 2014). Üreyen bakteri türlerinin yıllara göre dağılımı incelendiğinde ise dağılımın her üç yılda da benzer olduğu ve anlamlı değişim göstermediği tespit edilmiştir ( $\mathrm{p}=0.148$ ) (Tablo 1 ).

Acinetobacter türleri birçok antibiyotiğe intrinsik direnç göstermeleri ve çeşitli sınıf antibiyotiklere hızlı direnç geliştirme potansiyeline sahip olmaları nedeniyle yüksek mortalite ve morbidite ile seyreden ciddi hastane enfeksiyonlarına sebep olmaktadır (Eroğlu ve ark. 2015). Acinetobacter baumannii enfeksiyonlarının tedavisinde sıklıkla tercih edilen karbapenemlere karşı tüm dünyada ve ülkemizde son yıllarda direnç artışı göze çarpmakta ve özellikle YBÜ'lerinde karşılaşılan bu durum tedavi seçeneklerini kısitlamaktadır (Royer ve ark. 2015, Feretzakis ve ark. 2019, Uğur ve ark. 2019, Şahin ve ark. 2019). 2016 yılı Ulusal Antimikrobiyal Direnç Sürveyans Sistemi (UAMDSS) verilerine göre invaziv Acinetobacter spp. izolatlarında \%92.3 olarak tespit edilen yüksek karbapenem direnci, durumun ülkemiz için ciddi boyutlara ulaştığını bir kez daha ortaya koymuştur (UAMDSS Raporları [http://uamdss.thsk.gov.tr/] (Erişim tarihi: Şubat 2020). Çalışmamızda izole edilen A.baumannii suşlarının antibiyotiklere direnç oranları incelendiğinde; literatür ile uyumlu olarak, imipenem ve meropeneme \%94, siprofloksasine \%97, piperasilin-tazobaktama \%98, amikasine \%64 direnç gösterdiği saptanmıştır. Antibiyotik direncinin yıllara göre dağılımı incelendiğinde yukarıda bahsedilen antibiyotikler için her üç yılda da yüksek direnç saptandığı, dağılımın yıllar içinde anlamlı değişim göstermediği görülmüştür ( $>00.05)$ (Tablo 3 ).

Gram-negatif patojenler arasında, çoklu ilaç direnci ve son seçenek ajanlara (örn., kolistin) direnç dikkat çekici boyuttadır (Rhodes ve ark. 2019). Karbapenem dirençli A.baumannii enfeksiyonlarının artmasıyla birlikte tedavide yeniden gündeme gelen kolistin ile ilgili yurtdışında yapılan çalışmalarda farklı direnç oranları göze çarpmaktadır. Yunanistan'da yapılan bir çalışmada YBÜ'den izole edilen A.baumannii suşlarında \%53'lere varan direnç oranları tespit edilirken (Feretzakis ve ark. 2019), Amerika ve Avrupa ülkelerini kapsayan SENTRY sürveyans çalışmasında kolistin direnci \%5'den az bulunmuştur (Sader ve ark. 2014). Ülkemizdeki 2016 yılı sürveyans sonuçlarına göre, invaziv Acinetobacter spp. izolatlarında kolistin direnci \%6.7 olarak saptanmıştır. Benzer şekilde son yıllarda yapılan bazı ulusal çalışmalarda da düşük düzey kolistin direnci (\%1.8-\%2) bildirilirken (Özünel ve ark. 2014, Koçak ve ark. 2019), direncin rastlanmadığ yayınlar da mevcuttur (Sargun Altunok ve ark. 2014, Aydemir ve ark. 2016, Tartar ve ark. 2018). Bizim çalışmamızda da ulusal verilerle uyumlu olarak \%1 olarak bulunan direnç oranı kolistinin bu bakteriye karşı en etkili ajan olduğunu göstermiştir. Fakat direnç artışının önlenmesi için akılcı 
antibiyotik kullanımı doğrultusunda bu ajanın sadece yaşamı tehdit eden endikasyonlar için ayrılması gerektiği unutulmamalıdır.

Tigesiklin geniş spektrumlu bir antibiyotik olup karbapenemlere dirençli Acinetobacter suşlarında tercih edilebilecek bir ajandır (Şahin ve ark. 2019). Ülkemizde son yıllarda yapılan çalışmalar incelendiğinde direnç oranının \%5 ile \%49 arasında geniş bir aralıkta seyrettiği görülmektedir (Sargın Altunok ve ark. 2014, Cesur ve ark. 2017, Şahin ve ark. 2019). Çalışmamızda direnç oranı \%5 olarak bulunmuş ve tigesiklinin A.baumannii’ye karşı kolistinden sonra ikinci en etkili antibiyotik olduğu görülmüştür.

Başlıca nozokomiyal pnömoni etkenlerinden olan P.aeruginosa, çoklu antibiyotik direnci gösterebilmesi ve kullanılan antimikrobiyal ajanlara karşı hızlı direnç geliştirebilmesi nedeniyle özelikle yoğun bakımda izlenen hastaların tedavilerinde sorunlara neden olmaktadır (Demirdal ve ark. 2016, Wang ve ark. 2018, Rhodes ve ark. 2018). P.aeruginosa enfeksiyonlarının tedavisinde sıklıkla kullanılan antipsödomonal penisilinler, aminoglikozidler ve florokinolonlara karşı dünyada ve ülkemizde direncin arttığ gözlenmektedir (Rhodes ve ark. 2018, Tartar ve ark. 2018). Çalışmamızda seftazidim, piperasilin tazobaktam, amikasin ve siprofloksasin direnç oranları sırasılyla \%35, \%50, \%26 ve \%48 olarak bulunmuştur. UAMDSS 2016 verileri ile sonuçlarımız karşılaştırıldığında, amikasin için oranların benzer olduğu, ancak seftazidim, TZP (piperasilin-tazobaktam) ve siprofloksasisine direnç oranlarının bizim çalışmamızda az da olsa yüksek saptandığı görülmüştür. Çoklu ilaca dirençli P.aeruginosa enfeksiyonlarında kullanılan antibiyotiklerden imipenem ve meropenem ile ilgili ülkemizdeki son yıllara ait çalışmalarda direnç oranlarının sırasıyla \%29-\%70 ve \%26-\%63 arasında değiştiği bildirilmiştir ( Demirdal ve ark. 2017, Tartar ve ark. 2018, Uğur ve ark. 2019, Koçak ve ark. 2019, Hazırolan ve ark. 2016). Ülkemiz sürveyans verilerine göre ise invaziv P.aeruginosa izolatlarında karbapenem direnci \%46.1'dir. Bizim çalışmamızda imipenem direnci \%27, meropenem direnci ise \%19 olarak saptanmış olup ülkemiz ortalamasının altında bulunmuştur. Bununla birlikte karbapenemlere karşı artan direnç oranları P.aeruginosa enfeksiyonlarında kolistin kullanımını yaygınlaştırmıştır (İnce ve ark. 2014). P.aeruginosa suşlarına karşı kolistin duyarılığının bakıldığı çeşitli çalışmalarda Demirdal ve ark. ( Demirdal ve ark. 2017) kolistine direnç oranını \%1, Tümer ve ark. (2015) \%3.5, Uğur ve ark. (2019) \%5 olarak bildirmişlerdir. Ülkemiz sürveyans verilerine göre ise invaziv P.aeruginosa izolatlarında kolistin direnci \%5.2'dir (UAMDSS 2016). Çalışmamızda kolistin direnci benzer şekilde \% 6.5 olarak tespit edilmiştir.

K.pneumoniae ve E.coli'nin aralarında bulunduğu Enterobacteriacea grubu bakteriler endotrakeal aspirat örneklerinden sıklıkla izole edilmektedir (Rhodes ve ark. 2018, Wang ve ark. 2018, Koçak ve ark. 2019, Karakeçe ve ark. 2018). Avrupa ülkelerinde ve ülkemizde genişlemiş spektrumlu betalaktamaz oranlarının artması ile Enterobactericeae enfeksiyonlarında karbapenemler yaygın olarak klinik kullanıma girmiştir. Bunun sonucunda özellikle K.pneumoniae izolatlarında karbapenem direnci giderek artan oranlarda görülmeye başlamıştır. K.pneumoniae ve E.coli izolatlarında karbapenem direncini araştıran ulusal yayınlar incelendiğinde Karakeçe ve ark. (2014) bu oranları sirasıyla \%16 ve \%0, Aydemir ve ark. (2016) \%21 ve \%0, Koçak ve ark. (2019) \%42.4 ve \%1.7, Tartar ve ark.(2018) \%58 ve $\% 20$ olarak bulmuşlardır. Ülkemiz sürveyans verilerine göre ise karbapenem direnci K.pneumoniae ve E.coli için sırasıyla $\% 40.1$ ve $\% 5$ olarak saptanmıştır (UAMDSS 2016). Bizim çalışmamızda K.pneumoniae'da imipenem ve meropenem direnci $\% 29$ olarak bulunurken, E.coli'de meropenem direnci \%7.5 olarak saptanmış, imipenem direncine rastlanmamıştır. Tablo 2'de de görüldüğü gibi imipenem ve meropenem E.coli'de K. pneumoniae 'ya göre anlamlı düzeyde daha yüksek oranda bulunmuştur. Karbepenem direncinin yıllara göre dağılımı incelendiğinde iki bakteri için de, her üç yılda yüksek direnç saptandığı, direncin yıllar içinde anlamlı değişim göstermediği görülmüştür ( $>0.05)$. Ülkemizde K.pneumoniae ve E.coli suşlarının kolistin direnci ile ilgili çalışmalar incelendiğinde; Hacıseyitoğlu ve ark.nın (2014) çalışmasında her iki bakteri için de direnç saptanmazken, K.pneumoniae için Koçak ve ark. (2019) \%11, Koçak ve Hazırolan (2019) ise \%39.5 oranında direnç bulmuşlardır. Ülkemiz sürveyans verilerine göre ise invaziv K.pneumoniae ve E.coli suşlarında kolistin direnci sırasıyla \%17.5 ve \%3 olarak tespit edilmiştir. Çalışmamızda K.pneumoniae izolatlarında üç yıllık dönemde \%15 oranında kolistin direnci saptanmıştır. Dikkat çekici olarak 2016 yılında bu izolatlarda kolistin direnci gözlenmezken, 2018 yılına gelindiğinde ciddi bir artışla bu oran \%18.9'a ulaşmıştır. Üç yıllık süre zarfında saptadığımız kolistin direnci ülke ortalamasında olmakla birlikte oldukça yüksek bir düzeydedir. Ancak UAMDSS raporlarında da vurgulandığı gibi bizim çalışmamızda da kolistin direnci, EUCAST'ın önerdiği sıvı mikrodilüsyon yöntemi yerine otomatize sistem verileriyle elde edildiği için bu sonuçların gerçek direnç oranlarını yansıtmayabileceği akılda tutulmalıdır.

Çalışmamızda dikkat çekici olarak E.coli izolatlarının tamamının, K.pneumoniae izolatlarının ise \%92'sinin tigesikline duyarlı olduğu bulunmuş, sonuçlarımızın ülkemizde ve yurt dışında yapılan çeşitli çalışmalarla uyumlu olduğu görülmüştür (Hacıseyitoğlu ve ark. 2014, Çetin ve ark. 2014, Feretzakis ve

$261 \mid P$ a g e

www.iiste.org 
ark. 2019). Elde ettiğimiz bu oranlar hastanemizde tigesiklinin hem E.coli hem de K.pneumoniae enfeksiyonlarında halen kolistine uygun bir alternatif olduğunu göstermektedir.

Sonuç olarak, YBÜ’lerde izlenen hastalarda gelişen enfeksiyonların sıklıkla çoğul dirençli mikroorganizmalarla meydana geldiği unutulmamalıdır. VİP etkeni olarak ETA kültürlerinde üreyen mikroorganizma ve antibiyogram profilimize baktığımızda ünitemizde karbapenem direncinin A.baumannii suşlarında çok yüksek düzeyde olduğu, K. pneumoniae suşlarında ise kolistin direncinin yıllar içinde dikkat çekici oranda yükseldiği tespit edilmiştir. Bu yüksek oranlar, ünitemizde uygulanan enfeksiyon kontrol programlarının yeniden gözden geçirilmesi ve akılcı antibiyotik kullanım politikalarının uygulanmasında daha dikkatli olunması gerektiğini göstermektedir. Antimikrobiyal direnç paternlerinin düzenli olarak izlenerek tedavi protokollerinin bu doğrultuda güncellenmesinin, hem tedavi başarısına hem de direnç oranlarının azaltılmasına önemli katkı sağlayacağı düşünülmüştür. Çalışmamız hastanemiz YBÜ'nde enfeksiyon etkeni olan mikroorganizmaların direnç profillerinin belirlenmesi ve ampirik tedavinin planlanması konusunda klinisyenler için yol gösterici olacaktır.

\section{Kaynaklar}

Aydemir, Ö., Demiray, T., Köroğlu, M., Aydemir, Y., Karabay, O., Altındiş, M. (2016). Yoğun bakım ünitelerinde yatan hastaların endotrakeal aspirat örneklerinden izole edilen bakterilerin tanımlanması ve antibiyotik duyarlılıkları. Online Türk Sağlık Bilimleri Dergisi, 1: 1-8

Cesur, S., Irmak, H., Yalçın, N.A., Berktaş, M., Baysan, B., Kınıklı, S., Demiröz, A. (2017). Yoğun bakım ünitesinde yatan hastaların çeşitli kültür örneklerinden izole edilen Acinetobacter baumannii suşlarının antibiyotik duyarlılıkları. Ortadoğu Tıp Dergisi, 9; 51-55

Chung DR, Song JH, Kim SH, Thamlikitkul V, Huang SG, Wang H, So TM, Yasin RM, Hsueh PR, Carlos CC, Hsu LY, Buntaran L, Lalitha MK, Kim MJ, Choi JY, Kim SI, Ko KS, Kang CI, Peck KR; Asian Network for Surveillance of Resistant Pathogens Study Group. (2011). High prevalence of multidrug-resistant nonfermenters in hospital-acquired pneumonia in Asia.Am J Respir Crit Care Med, 84:1409-1417

Çetin, F., Mumcuoğlu, İ., Aksoy, A., Gürkan, Y., Aksu, N.(2014). Kan kültürlerinden izole edilen mikroorganizmalar ve antimikrobiyal duyarlılıkları. Turk Hij Den Biyol Derg, 71: 67-74

Demirdal, T., Şen, P., Yula, E., Kaya, S., Nemli, S.A., Demirci, M. (2017). Yoğun bakım ünitelerinden izole edilen Pseudomonas aeruginosa suşlarının direnç profilleri: Beş yıllık değerlendirme. Ortadoğu Tıp Derg, 9:108-112

Djordjevic Z.M., Folic M.M., Jankovic S.M. (2017). Distribution and antibiotic susceptibility of pathogens isolated from adults with hospital-acquired and ventilator-associated pneumonia in intensive care unit. J Infect Public Health, 10:740-744

Eroğlu, C., Ünal, N., Karadağ, A., Yılmaz, H., Acuner, İ.Ç., Günaydın, M. (2016). Çeşitli klinik örneklerden 2006-2011 yilları arasında izole edilen Acinetobacter türleri ve antibiyotik duyarlılıklar1. Turk Hij Den Biyol Derg, 73:25-32

Feretzakis G, Loupelis E, Sakagianni A, Skarmoutsou N, Michelidou S, Velentza A, Martsoukou M, Valakis K,Petropoulou S, Koutalas E. (2019). A 2-Year Single-Centre Audit on Antibiotic Resistance of Pseudomonas aeruginosa, Acinetobacter baumannii and Klebsiella pneumoniae Strainsfrom an Intensive Care Unit and Other Wards ina General Public Hospital in Greece. Antibiotics (Basel). 15:8(2)

Gupta, R., Malik, A., Rizvi, M., Ahmed, M., Singh, A. (2017). Epidemiology of multidrug-resistant Gram-negative pathogens isolated from ventilator-associated pneumonia in ICU patients. J Glob Antimicrob Resist, 9:47-50 
Hacıseyitoğlu ,D., Çağ, Y., Başgönül, S., Özer, S. (2014). Çeşitli Klinik Örneklerden İzole Edilen Escherichia coli ve Klebsiella pneumoniae izolatlarının antibiyotiklere direnç durumu. Türk Mikrobiyol Cem Derg, 44:101-106

Hazırolan, G., Kanyılmaz, D., Mumcuoğlu, İ., Bodur, H., Yetkin, M.A., Aksu, N. (2016). Nozokomiyal enfeksiyon etkeni Gram negatif bakterilerin çeşitli antibiyotiklere karşı direnç durumu: Ankara Numune Eğitim ve Araştırma Hastanesi sürveyans verisi (2011-2015). ANKEM Derg, 30: 24-30

İnce, N., Geyik, M.F., Özdemir, D., Öksüz, Ş., Danış, A. (2014). Hastane infeksiyonu etkeni olan Pseudomonas aeruginosa suşlarının yıllara göre antibiyotik duyarlılıklarının karşılaştırılması. ANKEM Derg, 28:94-99

Karakeçe, E., Tayfur Demiray, T., Fergül Erdoğan F., Çiftci, İ.H. Endotrakeal aspirat örneklerinden izole edilen Gram negatif etkenler. Acıbadem Üniversitesi Să̆lık Bilimleri Dergisi, 5: 3

Koçak, A.A., Yayla, B., Güçlü, A.Ü., Mirza, H.C., İştar E.H., Alışkan H.E., Başustaoğlu, A. (2019) Adana'da bir Üniversite Hastanesinde izole edilen solunum yolu patojenleri ve antibiyotik direnç profillerinin değerlendirilmesi. Türk Mikrobiyoloji Cem Derg, 49:226-232

Koçak, C.E., Hazırolan, G. (2019). Karbapeneme dirençli Klebsiella pneumoniae klinik izolatlarında kolistin direnci. Türk Mikrobiyoloji Cem Derg, 49:17-23

Nazik, S., Topal, B., Şahin, A.R., Güler, S. (2018). Evaluation of antimicrobial resistance rates in Klebsiella isolates. Mediterr $J$ Infect Microb Antimicrob. 2018;7:8. http://dx.doi.org/10.4274/mjima.2018

Özünel, L., Boyacıŏ̆lu, Z.İ., Güreser, A.S., Taylan Özkan, A. (2014). Çorum Eğitim ve Araştırma Hastanesi'nde derin trekeal aspirat örneklerinden izole edilen Pseudomonas aeruginosa ve Acinetobacter baumannii suşlarının antimikrobiyal duyarlılık paternlerinin değerlendirilmesi. Turk Hij Den Biyol Derg, 71: 81-88

Rhodes, N.J., Cruce, C.E., O'Donnell, J.N., Wunderink, R.G., Hauser, A.R. (2018). Resistance trends and treatment options in Gram-negative ventilator-associated pneumonia. Curr Infect Dis Rep, $6: 20: 3$

Royer, S., Faria, A.L., Seki, L.M., Chagas, T.P., Campos, P.A., Batistão, D.W., Asensi, M.D., Gontijo Filho P.P., Ribas, R.M. (2015). Spread of multidrug-resistant Acinetobacter baumannii and Pseudomonas aeruginosa clones in patients with ventilator-associated pneumonia in an adult intensive care unit at a university hospital. Braz J Infect Dis, 19:350-357

Sader HS, Farrell DJ, Flamm RK, Jones RN. (2014). Antimicrobial susceptibility of Gram-negative organisms isolated from patients hospitalised with pneumonia in US and European hospitals: results from the SENTRY Antimicrobial Surveillance ProGram, 2009-2012. Int J Antimicrob Agents, 43: 328-334

Sağmak Tartar, A., Özer, A.B., Ulu, R., Akbulut, A. (2018). Microbiological evaluation of the pathogens isolated from the endotracheal aspirate samples of the patients followed in the intensive care units: A one-year retrospective analysis. Klimik Derg, 31: 56-60

Sargın Altunok, E., Koc, M.M. (2014). Yoğun bakım ünitesinden izole edilen Acinetobacter suşlarının yıllara göre antibiyotik direnç oranlarının karşılaştırılması. ANKEM Derg, 28:1-7

Şahin A.R., Doğruer, D., Nazik, S., Aktemur, A., Öksüz, H., Aral, M., Ateş, S. (2019). Hastane kökenli patojenlerde artan antimikrobiyal direnç sorunu: Acinetobacter baumannii. Online Türk Sağllk Bilimleri Dergisi, 4: 156-169 
Toksöz, V., Yılmaz, M. (2019). Ventilatör ilişkili pnömoni hastalarından izole edilen mikroorganizmaların antimikrobiyal duyarlılıkları. Dicle Med J, 46:641-647

Tümer, S., Kirişçi, Ö., Özkaya, E., Çalışkan, A.(2015). Çeşitli klinik örneklerden izole edilen Pseudomonas aeruginosa suşlarının antibiyotik duyarlılıkları. ANKEM Derg, 29:99-104.

Uğur, M., Genç, S. (2019). Yoğun bakım ünitelerinden izole edilen Acinetobacter baumannii ve Pseudomonas aeruginosa suşlarının üç yıllık direnç profili. Turk J Intensive Care, 17:130-137

Ulusal Antimikrobiyal Direnç Sürveyans Sistemi (UAMDSS) 2016 Yıllık Raporu, Türkiye Halk Sağlığ 1 Kurumu, Sağlık Bakanlığı Ankara. http://uamdss.thsk.gov.tr [Erişim Tarihi: Şubat 2020]

Wang,Y., Zhang,R., Liu,W.(2018). Distribution and drug resistance of pathogenic bacteria in ventilator-associated pneumonia at a local hospital of North-eastern China. Infect Drug Resist, 13: $11: 22$ 